\title{
KARAKTERISASI SIFAT FISIK, KIMIA DAN SENSORIS BIHUN BERBAHAN TEPUNG KOMPOSIT GANYONG (Canna edulis) DAN KACANG HIJAU (Vigna radiata)
}

\author{
Physicochemical and Sensory Properties of Vermicelli Made from Canna (Canna edulis) and \\ Mungbean (Vigna radiata) Composite Flour
}

\author{
Jumanah Jumanah $^{1)}$, Maryanto Maryanto ${ }^{1)}$, Wiwik Siti Windrati ${ }^{1) *}$ \\ ${ }^{1)}$ Jurusan Teknologi Hasil Pertanian, Fakultas Teknologi Pertanian, Universitas Jember \\ Jalan Kalimantan 37, Kampus Tegal Boto Jember 68121 \\ *E-mail: wiwik.ftp@gmail.com
}

\begin{abstract}
Vermicelli is a processed product with yarn forms which are made from rice flour. Canna flour can replace the main ingredient of rice flour in making vermicelli. The manufacture of vermicelli flour composite requires protein ingredients such as mung bean flour to increase the protein content of vermicelli. The purpose of this study was to determine the good ratio of manufacture of vermicelli made from canna and mung bean composite flour and knowing the best formulation based on the most preferred of vermicelli. The research used Completely Random Design (CRD) with one factor method i.e substitution of canna flour and mung bean flour with five variations treatments. The treatments were controls (vermicelli rice commercial), P1 (60\%:5\%:35\%), P2 (50\%:15\%:35\%), P3 (40\%:25\%:35\%), P4 (30\%:35\%:35\%), P5 (20\%:45\%:35\%). This result showed that the ratio of canna flour and mung bean flour effected on ash content, fat content, protein content, carbohydrate, color, rehydration, elasticity and organoleptic, but no effected on moisture content, taste, flavor and overall. Vermicelli favored on P4 treatment (30\%: 35\%: 35\%) produced had value of preferences color 5,46 (netral), flavor 5,46 (neutral), taste 5,23 (nettral), texture 5,92 (netral), overall 5,92. Chemical properties of moisture content $9.85 \%$, ash content $0.05 \%$, fat content $1.74 \%$, protein content $9.83 \%$, carbohydrate content $78,60 \%$, and color (lightness) 54,94, elasticity 7,32 \%and power of Rehydration $24,77 \%$.
\end{abstract}

Keywords: vermicelli, canna flour, mung bean flour, tapioca

\section{PENDAHULUAN}

Bihun merupakan pangan yang mengandung karbohidrat, biasanya terbuat dari tepung beras yang diolah melalui proses ekstruksi sehingga diperoleh bentuk seperti benang. Bahan dasar pada pembuatan bihun masih bergantung pada tepung beras. Beras sebagai bahan pangan pokok sumber karbohidrat yang memiliki kandungan amilosa dan amilopektin yang tinggi (FAO, 2007). Tingginya kadar amilosa dalam beras memungkinkan bahan pangan tersebut sering diolah menjadi produk bihun. Kandungan amilosa tepung beras menjadi indikator penentu mutu bihun yang dihasilkan. Beras dengan amilosa tinggi memberikan sifat kekerasan yang lebih tinggi, daya regang dan kekentalan yang tinggi. Beras yang digunakan sebagai bahan baku pembuatan bihun yaitu beras yang mengandung amilosa tinggi, yaitu sekitar 25-30\% (Tungtrakul, 1998). Kandungan amilosa yang tinggi diperlukan untuk struktur bihun yang kompak (Mestres et al., 1988). Beras sebagai bahan pokok pangan masyarakat di Indonesia akan meningkat kebutuhannya. Hal ini terbukti Indonesia sebagai Negara pengimpor beras terbesar ke-7 di dunia. Menurut BPS (2015), jumlah impor beras pada tahun 2014 mencapai $84.163,7$ ton. Dalam rangka mengurangi impor beras, perlu dilakukan diversivikasi pangan yang dibuat dari bahan pengganti beras yaitu pangan lokal. Salah satu alternatif baru yaitu 
pemanfaatan bahan pangan lokal dengan menggunakan umbi ganyong.

Ganyong (Canna edulis) adalah salah satu komoditas pangan lokal di Indonesia. Ganyong sangat mudah untuk dibudidayakan pada tanah yang subur maupun tandus serta pada dataran tinggi dan rendah. Umbi ganyong di daerah Jawa Timur cukup melimpah sekitar 700 ton/tahun yang tersebar di wilayah Trenggalek, Ngawi, Nganjuk, Banyuwangi, Bojonegoro dan Malang. Ganyong memiliki kandungan serat dan mineral yang cukup tinggi. Namun, pemanfaatan ganyong hanya direbus ataupun dikukus, sehingga variasi pengolahan lanjutan umbi ganyong terbatas. Peningkatan variasi pemanfaatan ganyong yaitu dengan diolah menjadi tepung ganyong. Tepung ganyong mengandung karbohidrat 85,20 gram/100 gram, serat 2,204 gram/100 gram dan protein 0,70 gram/100 gram (Direktorat Gizi Depkes RI, 1989). Kandungan gizi tepung ganyong, memiliki prospek yang tinggi apabila diproses dengan baik karena sebagai alternatif sumber karbohidrat.

Menurut Ladamay (2014) Kacang hijau mengandung karbohidrat dan protein yang tinggi. Kacang hijau dapat diolah menjadi tepung dan dapat diaplikasikan dalam pembuatan berbagai olahan produk. Tepung kacang hijau memiliki kandungan karbohidrat sebesar $61,77 \%$ dan kadar protein sebesar $22 \%$.

Pemanfaatan tepung ganyong sebagai bahan dalam pembuatan bihun diharapkan dapat menganekaragamkan produk bebahan dasar ganyong. Oleh karena itu, penelitian ini dilakukan untuk mengetahui karakteristik bihun yang baik pada variasi penambahan tepung komposit ganyong, tapioka dan kacang hijau sebagai sumber protein sehingga dapat disukai.

\section{METODE PENELITIAN}

\section{Alat dan Bahan}

Peralatan yang digunakan dalam penelitian ini adalah timbangan, alat pencetak bihun (ekstruder), ayakan 80 mesh, kompor, pisau stainless steel, baskom, dandang, loyang, blender, oven, sendok. Alat untuk analisis meliputi colour reader (CR-10-Konica Minolta), peralatan kjehdal, eksikator, tanur pengabuan (Naberthem), kurs porselen, desikator, soxhlet (DET-GRAS N), destruksi, destilator (Buchi Distillation Unit K-355).

Bahan yang dipakai antara lain meliputi tepung ganyong dari Yogyakarta, kacang hijau yang diperoleh dari Kabupaten Jember dan tepung tapioka. Bahan untuk analisis kimia meliputi $\mathrm{H}_{2} \mathrm{SO}_{4}, \mathrm{HCl}, \mathrm{NaOH}$, petroleum benzene, asam borat, aquades, selenium, indikator methyl bue dan methyl red.

\section{Tahapan Penelitian}

\section{Pembuatan tepung kacang hijau}

Pada pembuatan tepung kacang hijau yang pertama dilakukan yaitu biji kacang hijau dibersihkan dari kotoran dan biji yang rusak. Setelah itu kacang hijau dicuci menggunakan air mengalir dan direndam selama 8 jam. Tahap selanjutnya biji kacang hijau dikupas kulit bijinya. Selanjutnya biji kacang hijau dikeringkan menggunakan oven pada suhu $60^{\circ} \mathrm{C}$ selama 18 jam. Kemudian biji dihaluskan menggunakana blender. Tahap selanjutnya tepung diayak menggunakan ayakan 80 mesh dan didapatkan tepung kacang hijau.

\section{Pembuatan bihun}

Campuran tepung ganyong, tepung kacang hijau dan tapioka dengan rasio 60:5:35, 50:15:35, 40:25:35, 30:35:35, 20:45:35 dan ditambah air panas $45 \%$ dari campuran tepung ganyong, teppung kacang hijau dan tapioka. Tahap selanjutnya dilakukan pembuatan adonan dilakukan dengan cara meremas-remas adonan hingga tercampur rata. Tahap 
berikutnya adonan dikukus selama 45 menitsupaya terjadi proses gelatinisasi. Adonan yang telah dikukus selanjutnya dicetak menggunakan ekstruder setelah itu distempering selama 10 menit dan selanjutnya dikeringkan pada suhu $50^{\circ} \mathrm{C}$ selam 24 jam

\section{Rancangan Percobaan}

Rancangan percobaan yang digunakan pada penelitian ini adalah Rancangan Acak Lengkap (RAL) dengan faktor tunggal yaitu formulasi tepung kacang hijau dan tepung ganyong dengan lima variasi perlakuan yaitu perbandingan jumlah tepung ganyong dengan tepung kacang hijau yang ditambahkan dan dilakukan sebanyak tiga kali ulangan. Data yang diperoleh akan dianalisis menggunakan uji sidik ragam (ANOVA) pada taraf $5 \%$ dan jika terdapat beda nyata akan dilanjutkan dengan uji Duncan New Multiple Range Test (DNMRT).

\section{Metode Analisis}

Analisis yang dilakukan pada penelitian ini meliputi analisis kimiawi, fisik dan sensoris. Analisis kimiawi meliputi kadar air, kadar protein, kadar abu, kadar lemak (Sudarmadji et al., 1997), kadar karbohidrat (Winarno, 2004). Analisis sifat fisik meliputi warna, daya dehidrasi dan elastisitas.

\section{Warna menggunakan color reader}

Pengukuran warna dilakukan dengan menggunkan color reader. Pengukuran diawali dengan standarisasi color reader dengan cara menghidupkan colour reader, kemudian lensa diletakkan pada keramik standard an menekan tombol "Target" maka akan muncul nila L, a, b pada layar yang merupakan nilai standarisasi. Selanjutnya colour reader ditempelkan pada permukaan bahan yang diamati dan menekan tombol "Target" kembali, sehingga muncul nilai $\mathrm{dE}, \mathrm{dL}$, da, $\mathrm{db}$. Pengukuran dilakukan sebanyak tiga kali ulangan pada beberapa titik yang berbeda dan dirata-rata.

Tingkat kecerahan diperoleh berdasarkan rumus:

$$
\mathrm{L}=\frac{\mathrm{L} \text { Standart }(94,35) \times \mathrm{L} \text { sampel }}{\mathrm{L} \text { Standar Keramik }(90,00)}
$$

Keterangan: Nilai kecerahan (L) berkisar antara $0-100$ yang menunjukkan warna hitam hingga putih.

\section{Daya rehidrasi (Ramlah,1997)}

Daya rehidrasi adalah banyaknya air yang terserap kedalam smapelpada waktu pemanasan. Pengukuranya dengan cara menimbang bihun (x gram), kemudian ditambahkan air panas selam 3 menit. Setelah itu ditiriskan dan ditimbang (y gram).

Daya rehidrasi $(\%)=\frac{y-x}{x} \times 100 \%$

Keterangan :

$\mathrm{x}=$ berat bahan awal sebelum penyeduhan $\mathrm{y}=$ berat bahan setelah penyeduhan

\section{Elastisitas (Ramlah, 1997)}

Elastisitas merupakan sifat tekstural yang berhubungan dengan konsistensi gel yang terbentuk. Pengukuran elastisitas dilakukan dengan menggunakan penggaris. Bihun yang telah dimasak diletakkan diatas penggaris dan diukur sebagai panjang awal $\left(\mathrm{y}_{1}\right)$, kemudian bihun ditarik hingga putus dan diukur panjangnya sebagai panjang akhir $\left(\mathrm{y}_{2}\right)$. Tingkat elastisitas dihitung dengan persamaan :

$$
\text { Elastisitas }=\frac{\mathrm{y} 2-\mathrm{y} 1}{y 1} \times 100 \%
$$

Keterangan :

$y 1=$ panjang awal setelah penyeduhan y2 = panjang ketika ditarik sampai putus

Uji sensori (Setyaningsih et al., 2010)

Pengujian sifat organoleptik dilakukan dengan uji scoring berdasarkaan kesukaan (Hedonis Scale Test). Cara pengujian dilakukan secara acak dengan sampel yang telah diberi kode 3 digit 
angka secara acak. Sebanyak 25 panelis tidak terlatih diminta untuk mengemukakan tingkat kesukaan tergadap sifat bihun yang meliputi warna, rasa, aroma, tekstur dan keseluruhan. Panelis diminta untuk memberikan skor berdasarkan skala yang telah ditentukan pada kuisioner. Skala penilaian yang digunakan adalah sebagai berikut :

1. Sangat tidak suka

2. Tidak suka

3. Agak tidak suka

4. Sedikit tidak Suka

5. Netral

6. Sedikit suka

7. Agak suka

8. Suka

9. Sangat suka

\section{HASIL DAN PEMBAHASAN}

\section{Sifat Kimia Bihun}

\section{Kadar air}

Kadar air pada bihun berkisar antara $8,4 \%$ - 10,51 \% dapat dilihat pada Gambar 1. Rasio tepung ganyong, tepung kacang hijau dan tapioka berpengaruh nyata terhadap kadar air bihun yang dihasilkan.

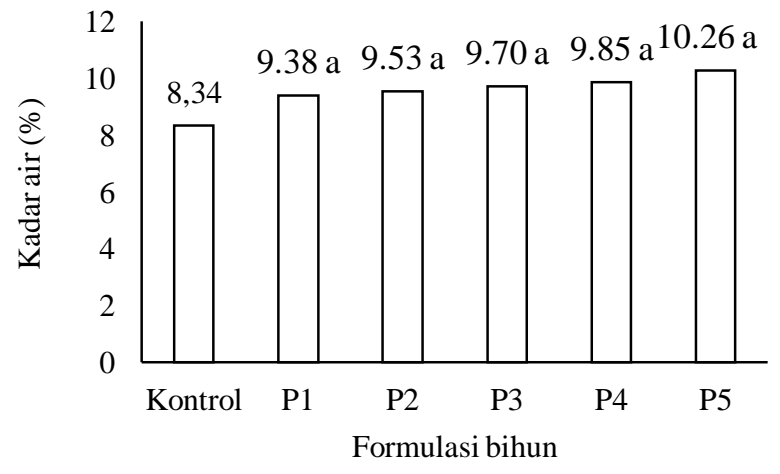

Gambar 1. Kadar air bihun tepung komposit ganyong dan tepung kacang hijau $8.34 \%-10.26 \%$.

Semakin tinggi proporsi tepung kacang hijau menghasilkan kadar air bihun semakin meningkat. Hal ini disebabkan karena kandungan protein tepung kacang hijau lebih tinggi $(22,2 \%)$ dibandingkan dengan tepung ganyong $(0.70 \%)$. Kadar air berkaitan dengan kandungan protein pada bahan yang digunakan, dimana air akan diikat oleh protein melalui ikatan hidrogen, karena melemahnya ikatan hidrogen ini maka molekul air dapat masuk diantara molekul protein dan pati (Soeparno, 2005).

Selain itu, kadar air juga dipengaruhi kadar pati pada bahan, kandungan pati pada tepung ganyong sebesar 40,2\% (Richana dan Sunarti, 2004), sedangkan kandungan pati pada tepung kacang hijau sebesar 30,9\% (Tan et al., 2006). Menurut Kearsley dan Dzeidzic (1995), kandungan amilosa dan amilopektin juga berpengaruh terhadap kadar air. Semakin tinggi kandungan amilosanya, maka akan semakin tinggi daya kadar air produk yang dihasilkan. Kandungan amilosa tepung ganyong sebesar $18,7 \%$ sedangkan tepung kacang hijau sebesar 33\%.

\section{Kadar $a b u$}

Kadar abu pada bihun berkisar antara $0.01 \%$ - $0.06 \%$. Rasio tepung ganyong, tepung kacang hijau dan tapioka tidak berpengaruh nyata terhadap kadar abu bihun yang dihasilkan.

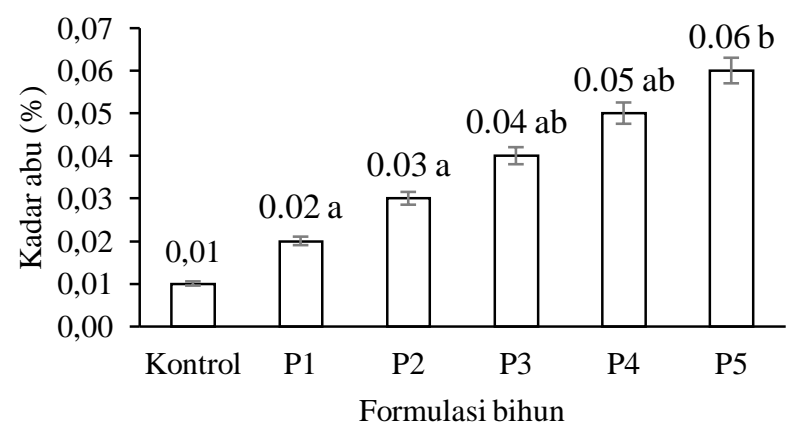

Gambar 2. Kadar abu bihun campuran tepung ganyong, tepung kacang hijau dan tapioka $0.01 \%-0.06 \%$

Semakin tinggi proporsi tepung kacang hijau yang ditambahkan, menghasilkan kadar abu yang dihasilkan semakin meningkat. Hal ini disebabkan karena tepung kacang hijau memiliki kandungan mineral yang cukup tinggi 
dibandingkan dengan tepung ganyong. Menurut Direktorat Gizi Depkes RI (1992) dalam 100 gram tepung ganyong terdapat kalsium sebanyak $21 \mathrm{mg}$, zat besi $1,9 \mathrm{mg}$ dan Fosfor $70 \mathrm{mg}$, sedangkan dalam 100 gram tepung kacang hijau terdapat kalsium sebanyak $125 \mathrm{mg}$, zat besi $6,7 \mathrm{mg}$ dan fosfor $320 \mathrm{mg}$.

\section{Kadar lemak}

Nilai kadar lemak bihun berkisar antara $1,21 \%$ - 3,27\%. Rasio tepung ganyong, tepung kacang hijau dan tapioka tidak berpengaruh nyata terhadap kadar lemak bihun. Hasil analisis kadar lemak bihun dapat dilihat pada Gambar 3.

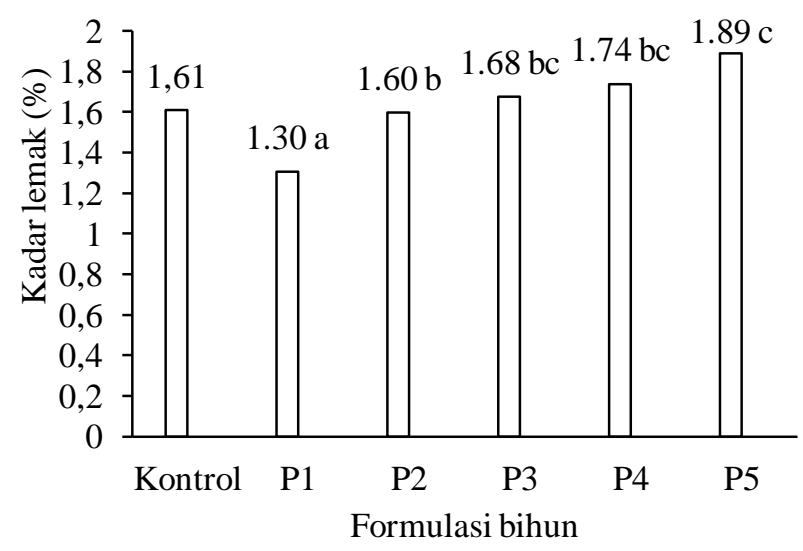

Gambar 3. Kadar lemak bihun campuran tepung ganyong, tepung kacang hijau dan tapioka $1.61 \%-1.89 \%$

Semakin tinggi proporsi tepung kacang hijau dan semakin rendah proporsi tepung ganyong menyebabkan kadar lemak bihun meningkat. Kadar lemak tepung kacang hijau lebih tinggi dibandingkan tepung ganyong. Menurut Direktorat Gizi Depkes RI (1989) kadar lemak tepung ganyong sebesar 0,20\%, sedangkan tepung kacang hijau sebesar $0,80 \%$. Lemak tepung kacang hijau lebih tinggi, semakin tinggi penambahan tepung kacang hijau, maka kadar lemak bihun yang dihasilkan semakin tinggi.

\section{Kadar protein}

Kadar protein bihun berkisar antara $2,04 \%$ - $12.78 \%$. Rasio tepung ganyong, tepung kacang hijau, tapioka berpengaruh nyata terhadap kadar protein bihun yang dihasilkan. Hasil analisis kadar protein dapat dilihat pada Gambar 4.

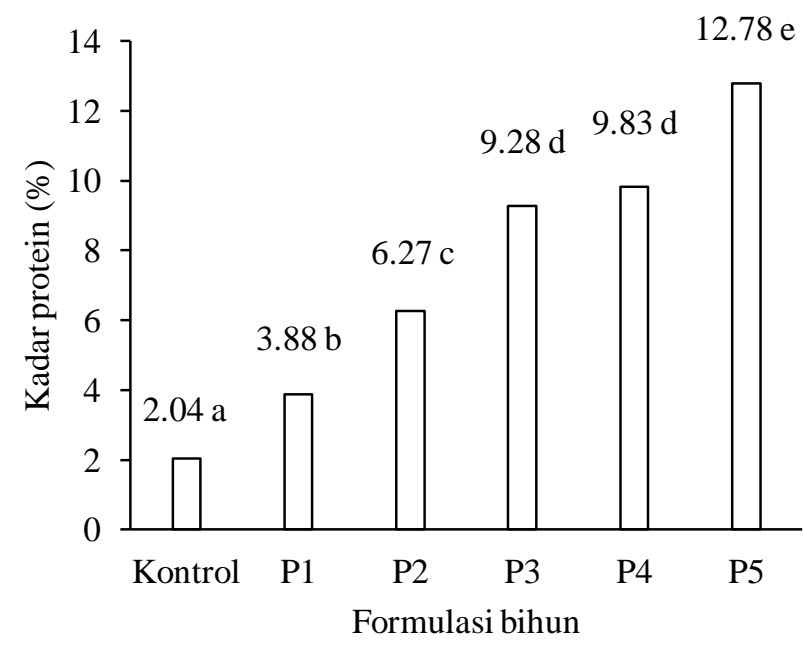

Gambar 4. Kadar protein bihun campuran tepung ganyong, tepung kacang hijau dan tapioka $2.04 \%-12.78 \%$

Seiring bertambahnya proporsi tepung kacang hijau yang ditambahkan dan menurunnya proporsi tepung ganyong menghasilkan kadar protein bihun yang dihasilkan.

\section{Kadar karbohidrat}

Rasio tepung ganyong, tepung kacang hijau dan tapioka berpengaruh nyata terhadap kadar karbohirat bihun yang dihasilkan. Hasil analisis kadar karbohidrat bihun dengan rasio penambahan tepung ganyong, tepung kacang hijau dan tapioka dapat dilihat pada Gambar 5. 


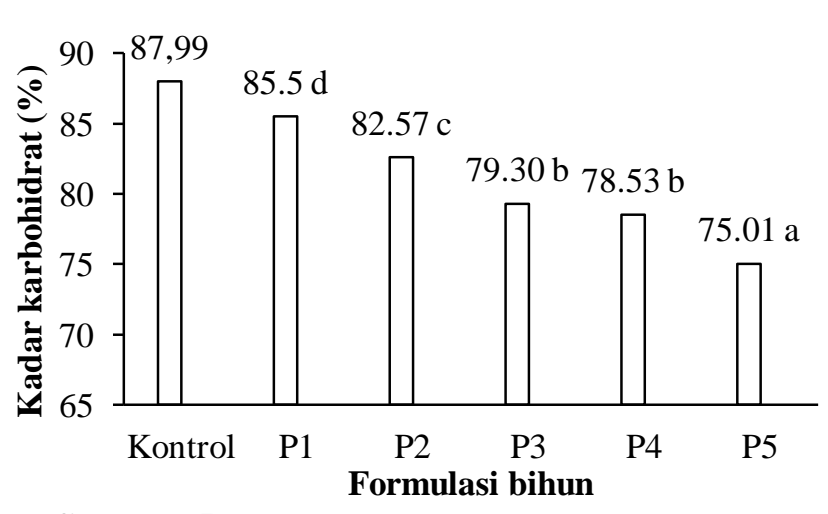

Gambar 5. Kadar Karbohidrat bihun campuran tepung ganyong, tepung kacang hijau dan tapioka $7.99 \%-75.01 \%$

Seiring bertambahnya proporsi tepung kacang hijau yang ditambahkan menghasilkna kadar karbohidrat bihun semakin menurun. Namun dengan semakin bertambahnya proporsi, tepung ganyong, kadar karbohidrat yang dihasilkan juga semakin tinggi. Menurut Sugito dan Ari Haryati (2006), kadar karbohidrat dipengaruhi oleh kadar komponen gizi lainnya. Semakin tinggi kadar komponen gizi lainnya, maka kadar karbohidrat akan semakin rendah, sedangkan apabila kadar komponen gizi lainnya semakin rendah, maka kadar karbohidrat semakin tinggi.

\section{Sifat Fisik Bihun}

\section{Warna (Lightness)}

Rasio nyata terhadap nilai lightness bihun. Nilai lightness yang dihasilkan sekitar 37,89-56,34. Hasil analisis terhadap warna (lightness) bihun dapat dilihat pada

\section{Gambar 6.}

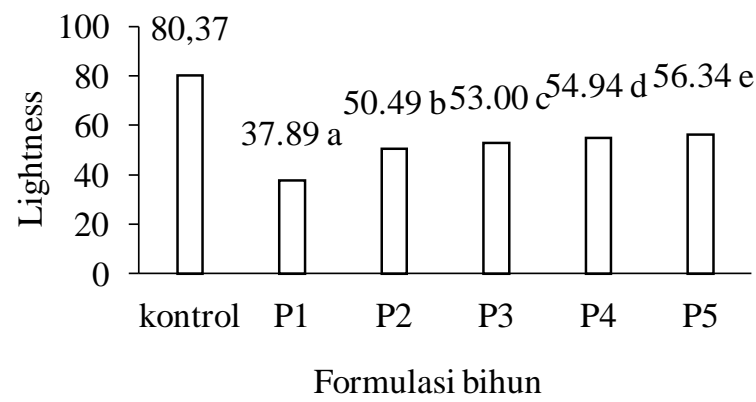

Gambar 6. Warna (Lightness) bihun campuran tepung ganyong, tepung kacang hijau dan tapioka 0.37-56.34
Seiring penurunan tepung ganyong dan proporsi tepung kacang hijau yang semakin tinggi menyebabkan nilai lightness semakin meningkat. Warna yang dihasilkan pada bihun ini dipengaruhi oleh bahan yang digunakan yaitu tepung ganyong, tepung kacang hijau dan tapioka. Menurut Fathullah (2013) salah satu karaktersitik fisik tepung ganyong yaitu memiliki warna putih kecoklatan. Warna tepung ganyong dipengaruhi oleh senyawa fenol dan aktivitas enzim fenolase atau polifenol Oksidase, pigmen dalam umbi, gum dan lender pada lapisan luar dan dalam jaringan umbi yang dapat membawa kotoran sehingga memberikan kenampakan warna yang agak gelap. Menurut Winarno (1994) rendahnya warna pada tepung ganyong disebabkan karena kandungan fenol yang lebih tinggi yang berakibat peningkatan aktivitas enzim fenolase sehingga menimbulkan warna coklat.

\section{Daya rehidrasi}

Rasio tepung ganyong, tepung kacang hijau dan tapioka berpengaruh nyata terhadap daya rehidrasi bihun. Hasil analisis daya rehidrasi bihun dapat dilihat pada Gambar 7.

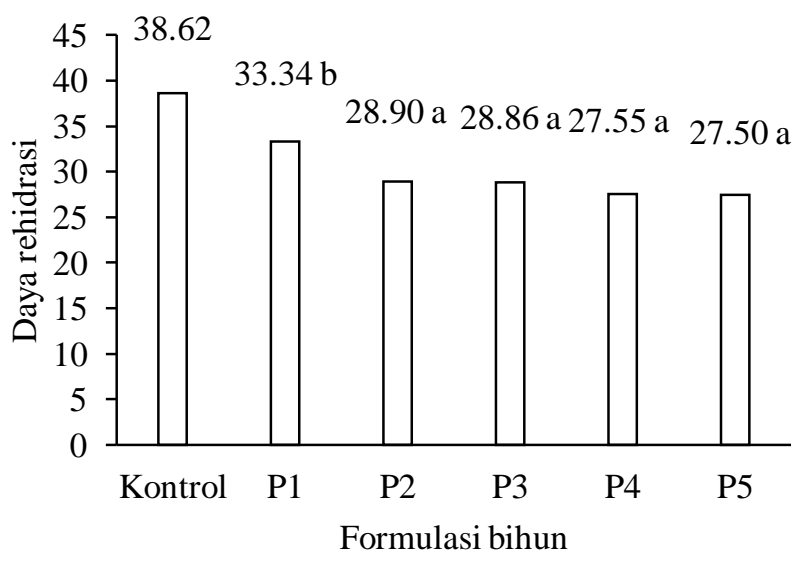

Gambar 7. Daya rehidrasi bihun campuran tepung ganyong, tepung kacang hijau dan tapioka 38.62-27.50\%

Semakin besar proporsi tepung ganyong yang ditambahkan dan proporsi tepung kacang hijau semakin sedikit 
menunjukkan daya rehidrasi bihun semakin meningkat. Hal ini dikarenakan kandungan pati pada tepung ganyong lebih besar daripada kandungan pati tepung kacang hijau. Seiring meningkatnya proporsi tepung ganyong menyebabkan kandungan pati meningkat. Kandungan pati pada tepung ganyong sebesar $40,2 \%$ (Richana dan Sunarti, 2004), sedangkan kandungan pati pada tepung kacang hijau sebesar 30,9\% (Tan et al., 2006). Menurut Widianingrum et al. (2005) daya rehidrasi (daya serap air) suatu bahan bergantung pada jumlah pati dalam adonan. Selain itu pati merupakan satu bahan yang bersifat hidrokoloid yang mampu mengikat air. Menurut Winarno (1922) pati kering yang sudah menalami gelatinisasi memiliki kemampuan menyerap air dengan mudah.

\section{Elastisitas}

Rasio tepung ganyong, tepung kacang hijau dan tapioka berpengaruh nyata terhadap elastisitas bihun. Hasil analisis elastisitas bihun dapat dilihat pada

\section{Gambar 8.}

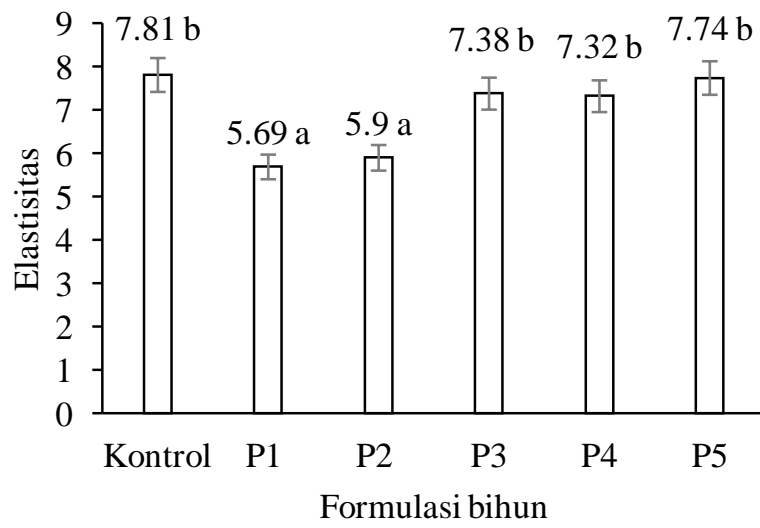

Gambar 8. Elastisitas bihun campuran tepung ganyong, tepung kacang hijau dan tapioka $5.69 \%-7.81 \%$

Semakin banyak proporsi tepung kacang hijau dan semakin sedikit proporsi tepung ganyong yang ditambahkan maka elastisitas bihun yang dihasilkan semakin tinggi. Hal ini disebabkan karena semakin banyak protein yang terdapat dalam bahan akan meningkatkan elastisitas pada bihun yang dihasilkan. Nilai elastisitas berhubungan dengan kadar protein. Kadar protein yang tinggi menghasilkan daya putus yang tinggi pula. Hal ini dikarenakan dengan semakin tinggi protein berarti semakin panjang ikatan peptidanya sehingga dibutuhkan energi yang lebih besar untuk memutuskan ikatan peptidanya tersebut (Hoseney, 1994).

\section{Sifat Sensori Bihun}

\section{Kesukaan warna}

Rasio tepung ganyong, tepung kacang hijau dan tapioka menunjukkan hasil yang berbeda nyata terhadap kesukaan warna. Hasil analisis warna dapat dilihat pada Gambar 9.

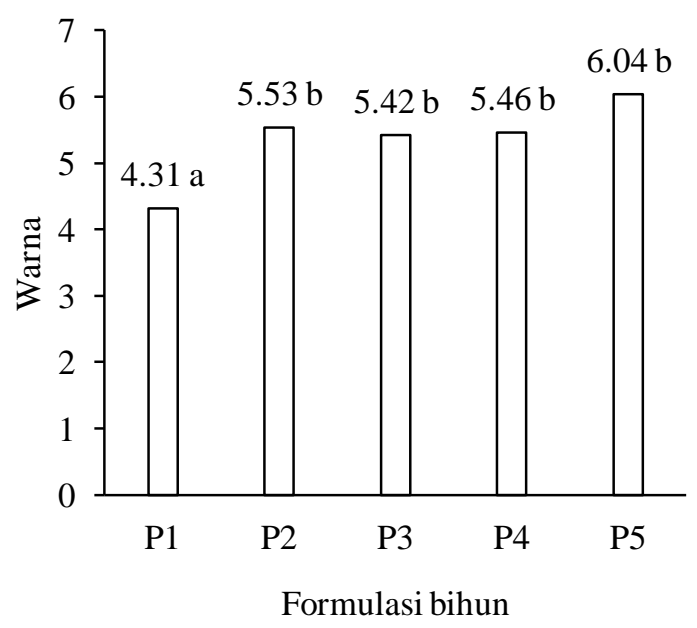

Gambar 9. Nilai kesukaan warna bihun campuran tepung ganyong, tepung kacang hijau dan tapioka $4.31 \%-6.04 \%$

Semakin tinggi proporsi penambahan tepung kacang hijau dan semakin sedikit proporsi tepung ganyong disukai panelis. Semakin tinggi proporsi tepung ganyong yang ditambahkan, maka warna bihun yang dihasilkan berwarna cokelat. Hal ini dikarenakan warna pada tepung ganyong dipengaruhi oleh senyawa fenol dan aktivitas enzim fenolase atau polifenol oksidase, pigmen dalam umbi, gum dan lender pada lapisan luar dan dalam jaringan umbi yang dapat membawa kotoran sehingga memberikan 
kenampakan warna yang rendah. Menurut Winarno (1994) rendahnya warna pada tepung ganyong disebabkan karena kandungan fenol yang lebih tinggi yang berakibat peningkatan aktivitas enzim fenolase sehingga menimbulkan warna coklat.

\section{Kesukaan aroma}

Rasio tepung ganyong, tepung kacang hijau dan tapioka menunjukkan hasil yang berbeda nyata. Hasil analisis terhadap aroma bihun dapat dilihat pada Gambar 10.

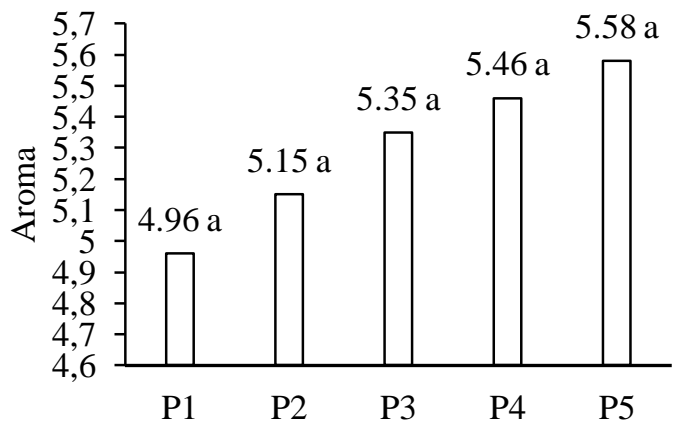

Formulasi Bihun

Gambar 10. Nilai kesukaan aroma bihun campuran tepung ganyong, tepung kacang hijau dan tapioka $4.96 \%-5.58 \%$

Semakin sedikit proporsi penambahan tepung ganyong nilai kesukaan terhadap aroma bihun semakin meningkat. Hal ini dikarenakan tepung ganyong memiliki aroma harum yang khas (Fathullah, 2013) sehingga panelis cenderung tidak menyukai aroma bihun dengan tingkat proporsi tepung ganyong yang lebih tinggi. Tepung Kacang hijau mempunyai aroma khas yaitu mempunyai sedikit bau langu. Bau langu disebabkan oleh aktivitas enzim lipoksigenase menyerang rantai asam lemak tidak jenuh dan menghasilkan sejumlah senyawa yang lebih kecil dari bobot molekulnya, terutama senyawa aldehid dan keton (Wieser, 2003).

\section{Kesukaan rasa}

Rasio tepung ganyong, tepung kacang hijau dan tapioka menunjukkan hasil yang berbeda nyata terhadap kesukaan rasa. Hasil analisis terhadap kesukaan rasa bihun dapat dilihat pada Gambar 11.

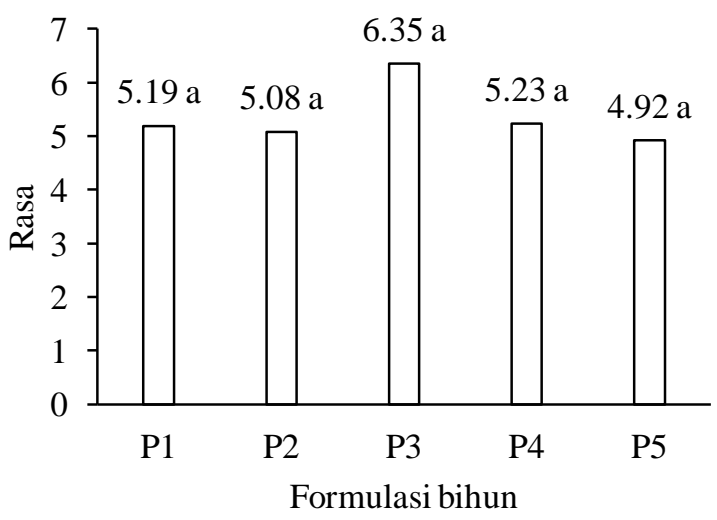

Gambar 11. Nilai kesukaan rasa bihun campuran tepung ganyong, tepung kacang hijau dan tapioka $4.92 \%-6.35 \%$

Semakin tinggi proporsi penambahan tepung ganyong dan semakin tinggi proporsi tepung kacang hijau nilai kesukaan terhadap rasa bihun menurun. Hal ini dikarenakan semakin tinggi proporsi tepung kacang hijau yang ditambahkan rasa bihun menjadi agak langu. Rasa langu ini ditimbulkan oleh senyawa off flavor. Rasa langu (beany flavor) disebabkan oleh enzim lipoksigenase yang menghidrolisa atau menguraikan lemak kacang hijau sehingga menimbulkan rasa langu (Sunaryo, 1985).

\section{Kesukaan tekstur}

Semakin tinggi proporsi penambahan tepung ganyong dan tepung kacang hijau menghasilkan nilai kesukaan panelis yang lebih rendah. Hasil analisis nilai kesukaan tekstur dapat dilihat pada Gambar 12. 


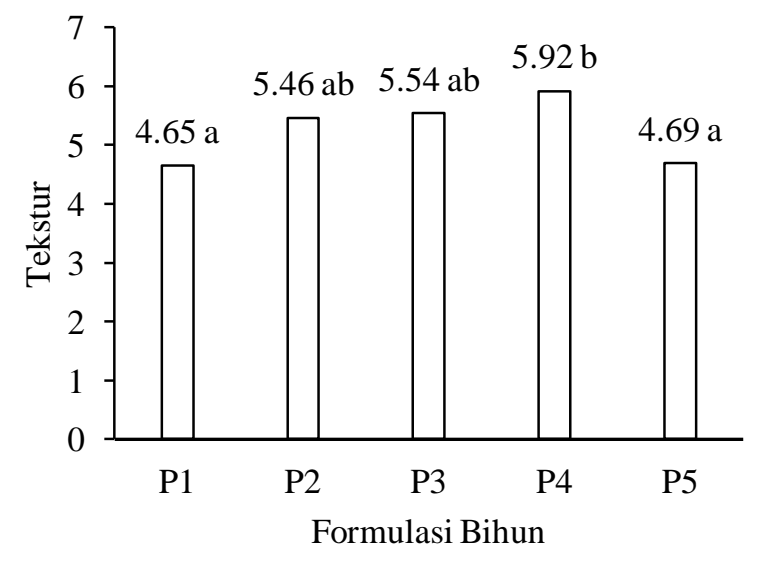

Gambar 12. Nilai kesukaan tekstur bihun campuran tepung ganyong, tepung kacang hijau dan tapioka $4.65 \%$ $5.92 \%$

Proporsi penambahan tepung ganyong dan kacang hijau mempengaruhi nilai kesukaan tekstur yang dihasilkan. Nilai kesukaan tekstur bihun tertinggi pada perlakuan P4 (rasio tepung ganyong : tepung kacang hijau : tapioka $=30 \%: 35 \%$ : 35\%) sebesar 5,92, sedangkan nilai terendah pada perlakuan P1 (rasio tepung ganyong : tepung kacang hijau : tapioka= $60 \%: 5 \%: 35 \%$ ) sebesar 4,65. Hal ini dikarenakan semakin rendah kandungan amilosa pada bahan menyebabkan struktur gel yang terbentuk semakin lemah dan menyebabkan padatan terlarut semakin besar sehingga tekstur bihun rendah (Rosa, 2007). Tekstur bihun juga dipengaruhi oleh kelengketan pada permukaan bihun karena molekul amilopektin membentuk daerah amorf atau kurang kompak, sehingga lebih mudah ditembus air (Alam et al., 2007). Tingkat elastisitas bihun yang disukai memiliki elastisitas sedang.

\section{Kesukaan keseluruhan}

Rasio tepung ganyong, tepung kacang hijau dan tapioka menunjukkan hasil yang berbeda nyata terhadap parameter keseluruhan. Hasil nilai kesukaan keseluruhan dapat dilihat pada Gambar 13.

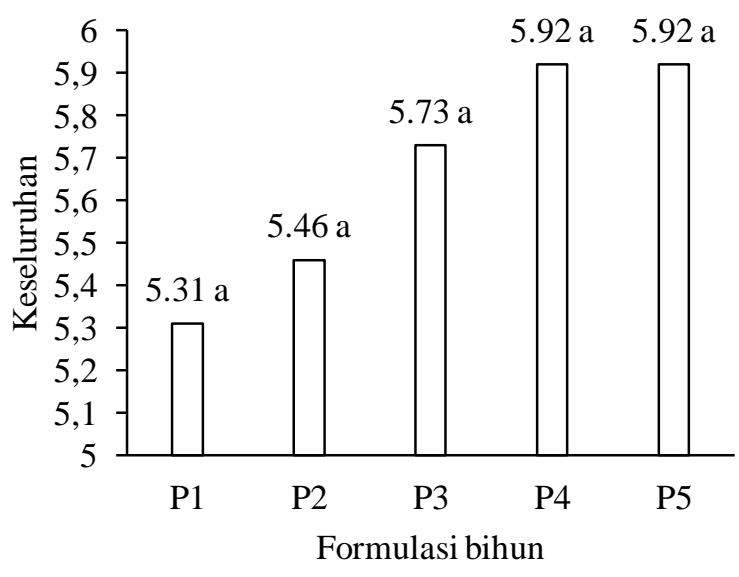

Gambar 13. Nilai kesukaan keseluruhan bihun campuran tepung ganyong, tepung kacang hijau dan tapioka $5.31 \%$ $5.92 \%$

Nilai tertinggi pada perlakuan P5 (rasio tepung ganyong, tepung kacang hijau dan tapioka $=20 \%: 45 \%: 35 \%$ ) sebesar 5,92, sedangkan nilai terendah pada perlakuan P1 (rasio tepung ganyong, tepung kacang hijau dan tapioka $=60 \%$ : $5 \%: 35 \%$ ) sebesar 5,31. jadi nilai kesukaan keseluruhan ditentukan oleh tekstur.

\section{KESIMPULAN}

Bihun formulasi yang paling baik berdasarkan bihun yang paling disukai terdapat pada perlakuan $\mathrm{P} 4$ rasio tepung ganyong : tepung kacang hijau : tapioka (30\%: $35 \%: 35 \%)$. Bihun yang dihasilkan mempunyai nilai kesukaan warna 5,46 (netral), aroma 5,46 (netral), rasa 5,23 (netral), tekstur 5,92 (netral), keseluruhan 5,92 (netral), kadar abu 0,05\%, kadar air $9,85 \%$, kadar lemak $1,74 \%$, kadar protein $9,83 \%$, elastisitas $7,32 \%$, daya rehidrasi $24,77 \%$, dan warna (lightness) 54,94.

\section{DAFTAR PUSTAKA}

Astawan, Made. 2009. Sehat Dengan Hidangan Kacang-kacangan dan Bijubijian. Penebar Swadaya, Jakarta.

Badan Pusat Statistik. 2015. Statistik Indonesia Tahun 2015. Badan Pusat Statistik, Jakarta. 
Badan Standarisasi Nasional. 1995. SNI.013724-1995. Cara Uji Makanan dan Minuman. Dewan Standarisasi Indonesia, Jakarta.

Direktorat Gizi. 1992. Daftar Komposisi Bahan Makanan. Departemen Kesehatan RI. Bhatara, Jakarta.

FAO. 2007. Field Food Crops : Rice, FAO Crop and Grassland Service (AGPC), Rome.

Fathullah, A. 2013. "Perbedaan Brownies Tepung Ganyong dan Kandungan Gizi". Skripsi. Jurusan Teknologi Jasa Dan Produksi Fakultas Teknik Universitas Semarang, Semarang.

Hoseney, R.C. 1994. Pasta And Noodles Principless of Cereal science and Technology. second Edition. Association of Cereal Chemists, Minnesota.

Hutchings, J. B. 1999. Food Color and Appearance. Aspen Publication, Maryland.

Mathews, R.H. 1989. Legumes: Chemistry, Technology and Human Nutrition. Marcel Dekker, Inc., New York and Basel. pp: 235.

Mestres, C., Colonna P. and Buleon, A. 1988. Characterization of Starch Networks Eithin Rice Flour Noodles and Mung bean Starch Vermicelli. Journal of Food Science, 53: 1809 - 1812.

Ramdhani, dkk. 2014. Bihun berbahan baku tepung garut dan kecambah kacang gude. Jurnal Pangan Agroindustry, 2 (4): 41-49.

Ratnaningsih, N., Mutiara, N., Titin, H.W.H., dan Ichda, C. 2010. Perbaikan Mutu dan Diversifikasi Produk Olahan Umbi Ganyong dalam Rangka Peningkatan Ketahanan Pangan. Artikel IbM Ganyong Nov 2010.
Richana, N dan Sunarti, T.C. 2004. Karakterisasi Sifat Fisiko kimia tepung umbi dan Tepung Pati dari Umbi Ganyong, Suweg, Ubi kelapa dan Gembili. Jurnal Pascapanen, 1 (1): 2937.

Setyaningsih., D. Apriyantono dan Sari, P.M. 2010. Analisis Sensori untuk Industri Pangan dan Agro. IPB Press, Bogor.

Soeparno. 2005. Ilmu dan Teknologi Pengolahan Daging. Gadjah Mada University Press, Yogyakarta.

Sudarmadji, S., Haryono, B. dan Suhardi. 1997. Prosedur Analisa Bahan Makanan dan Pertanian. Liberty, Yogyakarta.

Sugito dan Haryati. 2006. Penambahan daging ikan gabus (Ophicephallus strainus B LKR) dan aplikasi pembekuan pada pembuatan pempek gluten. Jurnal IlmuIlmu Pertanian Indonesia, 8 (2): 147151.

Sunaryo, E. 1985. Pengolahan Produk Serealia dan Biji-Bijian . FATETA-IPB, Bogor.

Susanto, T. dan Saneto, 1994. Teknologi Pengolahan Hasil Pertanian. PT. Bina Ilmu, Surabaya.

Tan, H, Z., Li, Z. G., Tan, B. 2006. Strach noodle: History, classification, materials, processing, structure, nutrition, quality evaluating and improving. Food Research International, 42 (5): 551-576.

Tungtrakul, P. 1998. Quality abd physicochemical properties of rice related to rice noodle . Report Natl. Food Res. Inst., 19.

Widianingrum, Sri, W., Dan Soewarno, T.S. 2005. Pengayaan Tepung Kedelai pada Pembuatan Mie Basah dengan Bahan Baku Tepung Terigu yang Disubstitusi Tepung Garut. Jurnal Pascapanen, 2 (1): 41-48. 
Wieser, H. 2003. Determination of Gliadin and Gluten in Wheat Starch by means of alcohol extraction ang gel permeation chromatography. In Stern.M.ed. Proceedings of the 17th Meeting of The Working group on Prolamin Analysis and Toxicity. Zwickau Verlag Wissenschaftliche Sripten, pp 53-57.

Winarno, F.G. 2004. Kimia Pangan dan Gizi. Gramedia Pustaka, Jakarta. 